\title{
NAVIGATING IDENTITY WITHIN THE CONTEXT OF CULTURE \& COMMUNITY: AN EXAMINATION OF CREATIVE ENGAGEMENT AMONG BLACK 2SLGBTQ CARIBBEAN-CANADIAN ARTISTS
}

\author{
by \\ Shaniqua (Nika) Smith, BSW, York University, 2019
}

\author{
An MRP \\ presented to Ryerson University \\ in partial fulfillment of the \\ requirements for the degree of \\ Master of Social Work \\ in the program of \\ Social Work
}

Toronto, Ontario, Canada, 2020

(C) Shaniqua (Nika) Smith, 2020 


\section{AUTHOR'S DECLARATION FOR ELECTRONIC SUBMISSION OF A MRP}

I hereby declare that I am the sole author of this MRP. This is a true copy of the MRP, including any required final revisions.

I authorize Ryerson University to lend this MRP to other institutions or individuals for the purpose of scholarly research.

I further authorize Ryerson University to reproduce this MRP by photocopying or by other means, in total or in part, at the request of other institutions or individuals for the purpose of scholarly research.

I understand that my MRP may be made electronically available to the public. 


\begin{abstract}
Navigating Identity Within the Context of Culture \& Community: An Examination of Creative Engagement Among Black 2SLGBTQ Caribbean-Canadian Artists

Master of Social Work, 2020

Shaniqua (Nika) Smith

Program of Social Work, Ryerson University
\end{abstract}

This research examines some of the ways Black 2SLGBTQ Caribbean-Canadian artists engage with creative expression to navigate their sexual and gender identities. This study also highlighted the intersection of race, gender, sexual identity, and immigration. The secondary data sources collected were a photography series produced by JamaicanCanadian photographer Brianna Roye; and a 2015 interview featuring Michèle Pearson Clarke, a Trinidadian-Canadian artist. These secondary data sources were analyzed using multi-textual analysis and qualitative content analysis tools. The findings highlight the potential for art and creative expression to address issues of anti-Black racism and heterosexism, in addition to fostering healing and community building. This study aims to present insight that will contribute to ongoing efforts within the social work profession to promote Black 2SLGBTQ equity and inclusion. 


\section{ACKNOWLEDGEMENTS}

Some educators may never know the profound impact they have made on the lives of their students. I am thankful to have crossed paths with agents of inspiration, hope, courage, and creativity. To Mr. Jones, Mr. Folkes, Dr. Liegghio, and Dr. Oba, thank you. I wish to extend my special gratitude to my research supervisor Dr. Gordon Pon for his unwavering guidance, understanding, and enthusiastic encouragement.

Finally, I would like to thank my friends and family for their care and support throughout this journey of growth and healing. 


\section{TABLE OF CONTENTS}

CHAPTER 1: INTRODUCTION.................................................

CHAPTER 2: LITERATURE REVIEW ............................................5

CHAPTER 3: THEORETICAL FRAMEWORK $\ldots \ldots \ldots \ldots \ldots \ldots \ldots \ldots \ldots \ldots \ldots \ldots \ldots \ldots . . \ldots \ldots$

CHAPTER 4: METHODOLOGY ................................................ 19

CHAPTER 5: FINDINGS \& ANALYSIS .......................................23

CHAPTER 6: IMPLICATIONS................................................ 39

CHAPTER 7: CONCLUSION...................................................43

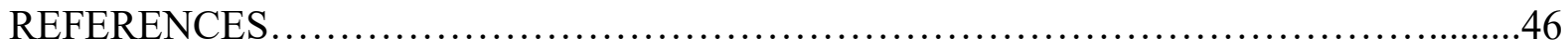




\section{LIST OF FIGURES}

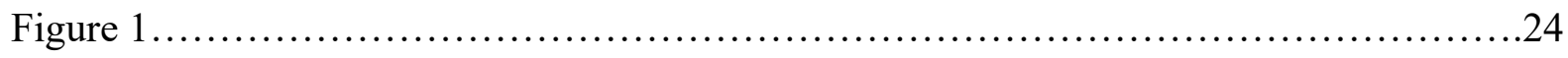

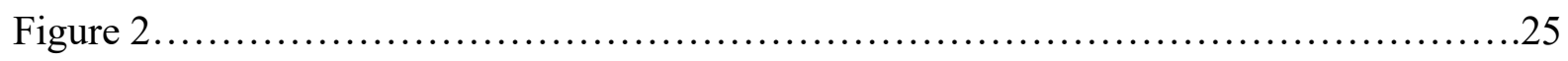

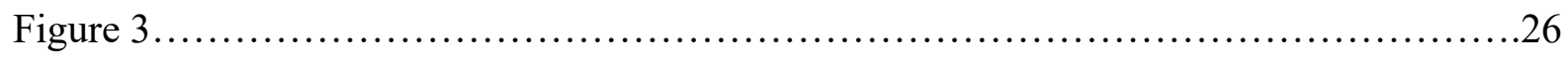

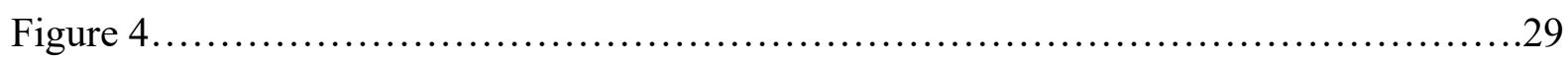

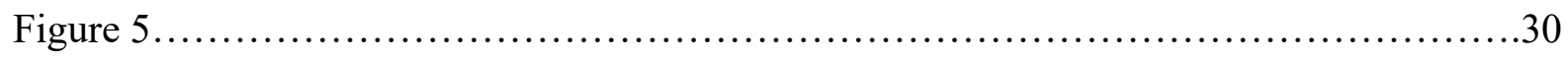

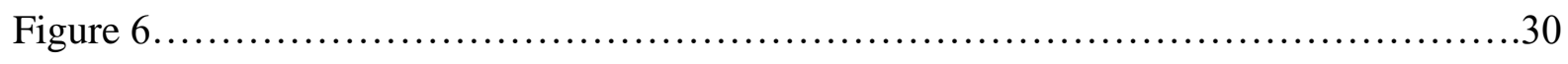

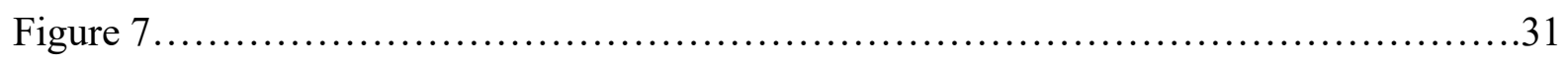

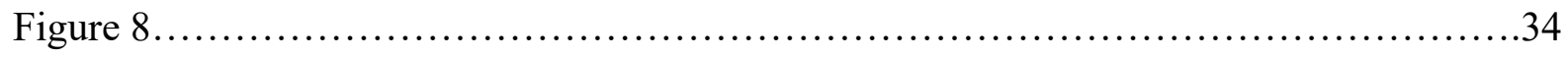

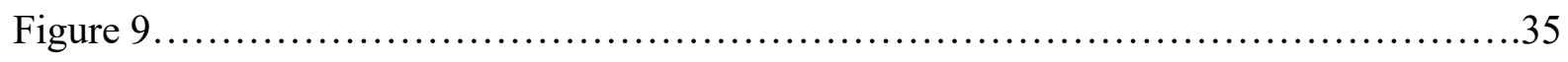




\section{CHAPTER 1. INTRODUCTION}

\section{Overview}

The purpose of this research is to contribute to the promotion of Black and Two-Spirit, Lesbian, Gay, Bisexual, Transgender, and Queer (2SLGBTQ) equity and inclusion. This research applies a critical race theory (CRT) theoretical framework to examine how Black 2SLGBTQ Caribbean-Canadian artists engage with creative expression to navigate their sexual and gender identities. How their art practice interacts with community and culture will also be analyzed. Also considered is the intersection of race, gender, sexual identity, and immigration. This research relied on secondary data sources. The secondary data sources include a photography project produced by Brianna Roye, a Black queer-identified Jamaican-Canadian photographer; and an interview featuring Michèle Pearson Clarke, a Black queer-identified TrinidadianCanadian artist. Multi-textual analysis and qualitative content analysis tools are used to collect and analyze the data in the form of the photography project and interview.

This research is important and unique because it centers Black 2SLGBTQ CaribbeanCanadians' knowledge and experience. Members of this population are doubly marginalized by anti-Black racism and cis-heterosexism and are underrepresented both within the larger 2SLGBTQ community and Caribbean community in Canada (Abreu, 2016; DeGagné, 2018; Toth, 2011; Wahab \& Plaza, 2009; Ware, 2017). Furthermore, this research contests the dominant notion that only evidence gathered through the scientific process qualifies as legitimate evidence or knowledge about racism and heterosexism (Hunter, 2002). The knowledge produced in this research could contribute to ongoing efforts within the social work profession to promote Black 2SLGBTQ inclusion. It is, therefore, also my aim to highlight creative engagement as a 
form of healing and resistance to the "larger forces that generate inequity, unfairness, and social injustice" (Mullaly, 2002, as cited in Baines, 2011, p. 46).

\section{Positionality}

I approach this research as a Black queer Jamaican-Canadian musician and social worker informed by the principles and values of anti-oppressive practice (AOP). My interest in this topic is further inspired by my passion for social justice and my experience with anti-Black racism and heterosexism. In some respect, my perspective is that of an insider (Humphrey, 2007). That is to say that I approach this topic with insight that is informed by my intersecting identities, knowledge, and lived experience. While I am also informed by the knowledge shared with me by other Black 2SLGBTQ-identified people, there are some limitations to my status as an insider. For instance, my existing knowledge does not necessarily capture the full reality and experience of those whose identities may be similar to mine. I am mindful of this distinction and invite alternative meanings and knowledge to surface throughout this research process.l]

\section{Definition of Terms}

The following is a list of key terms and definitions used to ensure a clear understanding of this research.

2SLGBTQ - Stands for Two-Spirit, Lesbian, Gay, Bisexual, Transgender, and Queer.

Anti-Black racism - A particular form of systemic and structural racism directed towards Black people.

Artist - An individual who actively engages in any area of the arts and produces material that is shared publicly.

Art practice - Refers to the process of creative expression; includes engaging in activities such as music-making (e.g., music production, songwriting, live performance, 
DJing), visual art forms (e.g., photography, videography, fashion, painting), creative writing (e.g., poetry, storytelling, slam poetry), as well as dance, and theatrical performances.

Caribbean-Canadian - A person who resides in Canada, who has either immigrated from the Caribbean or are descendants of Caribbean immigrants.

Community - A group of people who are linked by shared interests, values, experiences and/or goals.

Culture - This research adopts a postmodern view of culture, recognizing it as complex, fluid, hybrid, and evolving (Pon, 2009).

Heterosexism - A form of systemic oppression; beliefs and practices that discriminate against people who do not identify as heterosexual.

\section{Chapter Summary}

This chapter provided an overview of this present research. I discussed my connection to the topic and provided a list of key terms and definitions that will be used throughout the study. In the following chapter, I will provide a review of the literature that explored the following themes: 1) Black 2SLGBTQ exclusion and marginalization; 2) how these experiences of exclusion and marginalization impact the mental health and quality of life of members of the 2SLGBTQ community, including Black 2SLGBTQ Caribbean-Canadian persons; and 3) the use of creative expression as a practice of resistance and healing. I will also briefly discuss the gaps and limitations identified in the literature. Chapter Three provides an overview of critical race theory (CRT), the theoretical framework through which this research will be examined. In Chapter Four, I will discuss multi-textual analysis as the research methodology utilized for this research, my rationale for selecting this methodology, as well as some of its limitations. This 
chapter will also outline the data collection and analysis processes. In Chapter Five, I discuss my findings and analysis, followed by Chapter Six wherein I present the implications of this research for social work practice, the identified limitations, and recommendations on addressing these limitations. 


\section{CHAPTER 2. LITERATURE REVIEW}

\section{Introduction}

This chapter begins with a brief outline of my process of locating literature on my research topic, including keywords that were used, the databases that were searched, and my process of discerning relevant literature from irrelevant literature. I will then discuss the three common themes that were identified in the literature review: 1) Black 2SLGBTQ exclusion and marginalization; 2) how these experiences of exclusion and marginalization impact the mental health and quality of life of members of the 2SLGBTQ community, including members of the Black 2SLGBTQ Caribbean-Canadian community; and 3) the use of artistic and creative expression as a practice of resistance and healing by members of the Black 2SLGBTQ Caribbean-Canadian community. I will also reflect on the gaps identified in the literature.

\section{Search Strategy}

I applied a variety of search strategies to locate current literature on this topic. The primary databases that I accessed were JSTOR, EBSCOhost, and ProQuest. These databases were accessed through the Ryerson University Library website. I also relied on Google Search to locate news articles, artist websites, magazine articles, and other relevant information. Through the aforementioned databases, I used a variety of combinations of keywords to locate articles that were relevant to my research. The number of results yielded, and their relevance depended on the keywords used. For instance, when using JSTOR, the keywords "LGBT + Music + Canada + Caribbean OR Jamaica" yielded 78,256 results. Although the results were extensive, I was able to locate a number of relevant and insightful literature on the topic using this combination of keywords. I found other combinations less successful, specifically “Arts OR Creativity + Black + Racism + Canada + LGBT.” Although this yielded 62 results, I found none of the articles listed 
relevant to my topic. Likewise, when using EBSCOhost, the keywords "LGBT OR lesbian OR gay OR homosexual OR bisexual OR transgender OR homosexual OR queer OR sexual minority + Caribbean + the arts" yielded 15 results, with only 2 being relevant to my research. Alternatively, using Google Search helped me locate online magazine articles/blogs, artist websites, and other insightful information. However, I had to refine my searches as the results were often extensive. For instance, using the keywords "Black LGBTQ Caribbean-Canadian Artists" produced over 2,000,000 results. I refined my search query to only include materials published between 2000-2020 to increase the likelihood of locating relevant and contemporary literature. This condensed the results to roughly 300 hits, which allowed me to more easily locate relevant information.

Articles retrieved from these databases were deemed relevant if they contained information on the experiences of 2SLGBTQ individuals in Canada more broadly, and more specifically Black 2SLGBTQ people of Caribbean descent. This includes Black 2SLGBTQ Caribbean refugees, asylum-seekers, immigrants or descendants of Caribbean immigrants. Additionally, articles were also selected if they discussed the use of creative engagement among marginalized/racialized 2SLGBTQ individuals and communities. Preference was given to Canadian content. However, articles published in Caribbean countries or elsewhere outside of Canada were also considered.

\section{Exclusion and Marginalization}

The historical legacy of anti-Black racism can be linked to discourses of good and evil, represented in strict binaries of lightness/darkness and pure/impure (Deliovsky \& Kitossa, 2013). Pro-Whiteness and anti-Blackness are therefore framed within a moral framework (Deliovsky \& Kitossa, 2013). As a particular form of systemic and structural 
racism directed towards Black people, anti-Black racism is kept alive in Canadian society by being "deeply entrenched in Canadian institutions, policies and practices, such that [it] is either functionally normalized or rendered invisible to the larger white society" (Morgan \& Bullen, 2015, as cited in Mullings, Morgan \& Quelleng, 2016, p. 23). Expanding further on this perspective, activist and scholar Akua Benjamin (2003) draws a distinction between "anti-Black racism" and the "theory of anti-Black racism." She submits that the “'theory of anti-Black racism' emphasizes the resistance against dominant power and power holders in society" (Benjamin, p. 62). The naming of antiBlack racism is therefore recognized as "a form of resistance against dominant and hegemonic systems of Whiteness and the building of agency and social transformation against racism and other forms of oppression" (Benjamin, 2003, p. ii).

This form of resistance continues in contemporary society in response to racial profiling, carding, over-policing of Black communities and other anti-Black policies and practices within Canadian society generally and, more specifically, law enforcement and culture (Davis, 2017; DeGagné, 2018; Morgan, Mullings \& Quelleng, 2016; Wortley \& Owusu-Bempah, 2011). A 2018 report on racial profiling and racial discrimination against Black people by the Toronto Police Service (TPS) found that "between 2013 and 2017, a Black person in Toronto was nearly 20 times more likely than a White person to be involved in a fatal shooting by the Toronto Police Service" (Ontario Human Rights Commission, 2018, p. 3). The report also confirmed that "Black people are much more likely to have force used against them by the TPS that results in serious injury or death" (Ontario Human Rights Commission, 2018, p. 19). 
Furthermore, the literature on the experiences of Black 2SLGBTQ communities reveals the unique forms of oppression that some members often confront on account of their intersecting identities. Coined by activist and legal scholar Kimberlé Crenshaw (2018), the term "intersectionality" refers to how systems of oppression interact with race, gender, class, ability, sexual orientation, etc., and shape individuals' lived experiences at multiple levels (i.e., micro, mezzo, macro). According to one research on the experiences of Black gay men, participants experienced a sense of self that combines race and sexuality into a larger identity (Wilson, 2007). Participants also expressed privileging one identity over the other (i.e., "Black-then-gay"), or that their race and sexual identities are separated between public and private spaces (i.e., race is a public identity and sexuality is a private identity [Wilson, 2007]).

Additionally, there are other challenges that 2SLGBTQ-identified Black, Indigenous and people of colour are more likely to experience. For instance, unlike their White LGBTQ counterparts, Black 2SLGBTQ people are more likely to be subjected to race-based discrimination, verbal or physical violence, and a lack of representation and inclusion in spaces and services due to racist policies and practices (Benn, 2017; Giwa \& Greensmith, 2012; O’Neill, Swan \& Mulé, 2015). Research also indicates that 2SLGBTQ-identified Black, Indigenous and people of colour are more likely to experience police profiling, harassment, and violence (DeGagné, 2018; Miller, 2017). Transgender women of colour are further marginalized due to racist, cisnormative, and transphobic practices and policies (Cader \& Amofah, 2016). Research also indicates that their specific needs often go neglected in shelters and housing programs, and they are more likely to experience verbal or physical harassment and violence than their White transgender counterparts (Cader \& Amofah, 2016; Miller, 2017; Pyne, 2015; Steinmetz, 2015). It is therefore crucial that this present research not only considers how race, 
gender, and sexual identities are experienced independently but also how they interact with one another (Giwa \& Greensmith, 2012; Hill, 2013; Hunter, 2010; Majied, 2015).

Black 2SLGBTQ people are also confronted with the issue of anti-Black racism within the larger 2SLGBTQ community in Canada (Giwa \& Greensmith, 2012; Shum, 2016). Black 2SLGBTQ members often confront exclusion from the larger 2SLGBTQ community due to a lack of adequate representation and services that meet their unique needs (Benn, 2017). This ongoing issue has been made explicit in instances where the narratives and concerns of Black 2SLGBTQ lives had been invalidated, silenced, delegitimized, and dismissed (DeGagné, 2018; Ware, 2017).

Consider, for example, Black Lives Matter (BLM) Toronto's sit-in protest during the 2016 Toronto Pride parade where the group seized the opportunity to call for increased accessibility for people with disabilities and better representation for Black, Indigenous and people of colour during Pride events (Keleta-Mae, 2020; Walcott \& Abdillahi, 2019). Also among their list of demands was an end to police involvement in Pride events. The group cited the tremendous impact that police presence at Pride has on particular members of the community—specifically trans women, Indigenous and Black people—who are disproportionately subjected to police harassment and violence (Black Lives Matter Toronto, n.d.; DeGagné, 2018). BLM Toronto's demonstration generated a mixture of responses from the crowd. Some chanted in solidarity, seeing this as a monumental step towards change. However, other members of the crowd were less receptive and dismissed the gesture as an unnecessary disruption (Gollom, 2016). There were reports of booing on the part of some White spectators, with some shouting, "Take this fight to Caribana" (Ware, 2017, p. 176). The intent behind these 
negative responses was clear: to silence and invalidate the rage expressed by BLM Toronto and discourage any future acts of resistance.

In an international context, Black 2SLGBTQ people are also subjected to homophobic and transphobic discrimination on account of their sexual/gender identities. In Caribbean countries such as Barbados, Guyana, Dominica, Jamaica, Trinidad and Tobago, the systemic oppression of 2SLGBTQ people — and general stigma surrounding non-heterosexual and gender diverse people - is found within the socio-cultural milieu and the legal system, which some argue may be remnants of the region's colonial past (Jackman, 2016; Lavers, 2019). Jamaica, for example, has been strongly criticized for its human rights violations against 2SLGBTQ people. Heterosexist sentiments in the region are further reinforced by the buggery law, which identifies consensual same-sex relations as a sinful and criminal act that is punishable by 10 years of hard labour (Charles, 2011; Human Rights Watch, 2014). The normalization of anti-LGBTQ violence, and little to no protection from the police, create an increased sense of fear and helplessness among 2SLGBTQ people (Alessi, Khan \& Horn, 2017; Human Rights Watch, 2014; LaViolette, 2009).

Some supporters of anti-2SLGBTQ sentiments in these regions cite religious belief as their main reason for their stance against sexual and gender minorities (Human Rights Watch, 2004). This is consistent with research suggesting a relationship between religiosity and the rejection of homosexuality (Benn, 2017; Ghabrial, 2014; Hill, 2013; Janssen \& Scheepers, 2019; Quinn \& Dickson-Gomez, 2015). Likewise, dancehall music and culture have aided in the international spread of anti-2SLGBTQ sentiments. As a global phenomenon, dancehall culture is known for its aggressive and deadly anti-2SLGBTQ rhetoric (Julien, 1996). The literature on the topic often reference songs such as Damn by Beenie Man, Pump Up by Sizzla, A Nuh Fi Wi 
Fault by Elephant Man, and Boom Bye-Bye by Buju Banton for their promotion and glorification of violence against 2SLGBTQ people (Abreu, 2016; Ghabrial, 2014).

\section{Mental Health \& Quality of Life}

Systemic oppression of 2SLGBTQ people promotes a culture of abuse, which creates issues around the health and safety of 2SLGBTQ individuals (Alessi, Khan \& Horn, 2017). Their quality of life may be significantly impacted as they are vulnerable to workplace harassment, familial abandonment, violence, homelessness, substandard health care, feelings of helplessness, depression, anxiety, post-traumatic stress disorder (PTSD), and other mental health-related issues (Alessi, Khan \& Horn, 2017; Quinn \& Dickson-Gomez, 2015). Some individuals are forced to remain invisible in an attempt to preserve their safety and escape prejudice and abuse (Human Rights Watch, 2014; Human Rights Watch, 2004).

Moreover, issues around housing, poverty, and mental health are common among Black 2SLGBTQ youth (Benn, 2017). Likewise, they are significantly less likely to disclose their sexual and gender identity to their families due to fear and cultural homophobia (Ghabrial, 2014). One study reported that $80 \%$ of White LGBTQ youth were out to their parents, compared to $61 \%$ of their Black LGBTQ counterparts (Benn, 2017). This silence can be further detrimental to their mental health and quality of life (Ghabrial, 2014).

There are several cases of 2SLGBTQ people forced to leave their country of origin in search of human rights protection due to incidents of homophobic or transphobic violence, and the impact these experiences have had on their safety and mental health (d'Entremont, 2012; LaViolette, 2009; Mulé \& Gates-Gasse, 2012; Murray, 2014). LGBTQ forced migrants and asylum-seekers are also more likely to experience depression, anxiety, substance dependence, post-traumatic stress disorder, and suicidality as a result of prolonged exposure to LGBTQ 
discrimination and violence (Alessi, Khan \& Horn, 2017; Ghabrial, 2014; Hopkinson et al., 2017).

\section{Creative Expression as a Practice of Resistance and Healing}

Research-based literature on the impact of creative engagement suggests that it can help promote emotional health and healing (Stuckey \& Nobel, 2010; Neilhart, 1998). Engaging in creative expression can significantly assist Black and 2SLGBTQ people of colour in constructing their social identities within cis-heteronormative and anti-2SLGBTQ cultures (Aiyer, 2020; Toth, 2011; Wilson 2007). Black 2SLGBTQ DJs and hip-hop artists, for instance, play a significant role in creating social change and transforming cultural spaces by facilitating space that is inclusive and representative of Black 2SLGBTQ experiences and voices (Toth, 2011; Ware, 2017; Wilson, 2007; Xtra Magazine, 2020). Engaging in creative art practices and artistic communities may also provide Black and 2SLGBTQ people of colour with a sense of validity, reassurance, hope and liberation, while also providing a platform on which to express their intersecting identities (Aiyer, 2020; Levitt et al., 2018; Wngz \& Ware, 2020).

Research also suggests that creative art therapies can improve mental health outcomes among refugees with depression and post-traumatic stress disorder (Akthar \& Lovell, 2018; Dieterich-Hartwell \& Koch, 2017). One study that examined the ways art therapy may benefit refugee children reported the following:

Children used storytelling as an avenue to integrate and share their experiences, suggesting that storytelling in art therapy acts as a method of unification allowing refugees to express, explore and make meaning of their traumatic experiences.

(Akthar \& Lovell, 2018, p. 146) 
A similar study that looked at the efficacy of talk therapy and creative arts-based therapy interventions aimed at supporting refugee and asylum-seeking children with mental health difficulties also found that "both the verbal processing-based and creative art-based interventions led to significant reductions in symptoms of depression, anxiety, PTSD, functional impairment, and peer problems" (Tyrer \& Fazel, 2014, p. 8).

\section{Limitations and Gaps in Literature}

There is a significant gap in the literature on the specific experiences of Black 2SLGBTQ Caribbean-Canadian people in the arts. Researchers working in tandem with members of this population to produce further information in this area could inform service providers, policymakers and the social work profession on how to better meet the needs of this community. Identifying and addressing these limitations would promote the inclusion of Black 2SLGBTQ Caribbean-Canadian people, and advance our efforts towards eradicating anti-Black racism in ways that are innovative and transformative. I aim to contribute to these ongoing efforts with the knowledge produced in this research. 


\section{CHAPTER 3. THEORETICAL FRAMEWORK}

\section{Introduction}

This chapter provides an overview of critical race theory - the theoretical framework on which this research is based. I will discuss how critical race theory relates to race and racism within the context of this research and explain my rationale for selecting this approach.

\section{Overview of Critical Race Theory}

This present research applies critical race theory (CRT) as the primary theoretical framework used to examine the use of creative expression among Black 2SLGBTQ CaribbeanCanadian artists. CRT is an interdisciplinary approach to analyzing and combating race inequity in society (Gillborn \& Ladson-Billings, 2019). As an extension of critical legal studies (a legal movement in the 1970s), CRT challenges the ubiquity of White experience "as the authoritative standard that binds people of color and normatively measures, directs, controls, and regulates the terms of proper thought, expression, presentation, and behavior" (Calmore, 1992, as cited in Ladson-Billings, 2000, p. 265). Primacy is placed on centering the knowledge systems and experiences of those oppressed by race, class, gender, and sexual identity; and sharing these experiences through the use of creativity, storytelling, narrative, and interdisciplinary treatment of law (Bell, 1995; Ladson-Billings, 2000).

Five foundational tenets guide CRT. The first tenet is concerned with the universality of racism. It asserts that racism is deeply imbued within the social fabric of Western society, and is therefore perceived as a normal and natural occurrence (Delgado \& Stefancic, 2017). The process of advancing racial social justice involves exposing the various areas in which racism is enmeshed in society (Ladson-Billings, 2000). Likewise, the proceeding core features of CRT assert that, as a society, we must actively commit ourselves to challenge dominant ideologies and 
fight for social justice. Ways of achieving this include applying an interdisciplinary perspective that recognizes people's complexity and the multiple social identities they embody. This aligns with the final tenet, which emphasizes the importance of centering the experiential knowledge of people of colour, as "minority status...brings with it a presumed competence to speak about race and racism" (Delgado \& Stefancic, 2017, p. 11).

Moreover, CRT highlights the importance of storytelling and narratives (Delgado \& Stefancic, 2017; Ladson-Billings, 2000). Counter-storytelling can be utilized as a tool to challenge, displace, or mock dominant oppressive narratives and beliefs (Delgado \& Stefancic, 2017). Powerfully written stories and narratives, according to Delgado and Stefancic (2017), "may begin a process of correction in our system of beliefs and categories by calling attention to neglected evidence and reminding readers of our common humanity" (p. 51). In other words, counter-storytelling is a method of bringing marginalized people from the peripheries, breaking their silence, and centering their experiences and knowledge.

\section{Race and Racism}

Race and racism, according to CRT, are intertwined and inform all aspects of society (Delgado \& Stefancic, 2017). Race is understood as a "primary structure of oppression that is rooted in colonialism, capitalism and patriarchy" (Yee, 2005, p. 90). As a social construct, it shapes not only our psyche but also every facet of society (Chen, 2017; Maynard, 2017). Absent from dominant narratives that depict Canada as racially diverse and inclusive is the country's history of the enslavement of Black people that was legally practiced for over two hundred years; state-sanctioned violence against Indigenous peoples perpetrated through the residential school system and the "Sixties Scoop"; and the legacy of these colonial practices (Cooper, 2006; Maynard, 2017; Truth and Reconciliation Commission of Canada, 2015). 
Furthermore, attendant to colonialism, capitalism, patriarchy, and racism is the ideology of White supremacy; the resulting impact of these interlocking oppressions is the marginalization and oppression of people of colour (Chen, 2017; Delgado \& Stefancic, 2017). This is evident in the differential access to many mainstream institutions, economic exclusion, and racialized policing that people of colour disproportionately confront (Ray, Randolph, Underhill \& Luke, 2017). Coupled with settler colonialism, White supremacy has also been a violent process of land domination, extermination, and assimilation of Indigenous peoples (Lawrence \& Dua, 2005; Smith, 2006; Tuck \& Yang, 2012). This historical and ongoing practice in settler nations serves to "ensure the ascendancy of White settlers as the true and rightful owners and occupiers of the land" (Tuck \& Yang, 2012, p. 12).

In Heteropatriarchy and the Three Pillars of White Supremacy, Smith (2006) submitted that one key notion of White supremacy is that Black lives are not only inferior, but they are also merely property. This, Smith asserted, equates Blackness with inherent "slaveability" (p. 68). The objectification and dehumanization of Black lives have long been a reality experienced by many Black people (Maynard, 2017). This phenomenon was also referenced by Fanon (1952) in Black Skin White Masks wherein he stated:

I arrive slowly in the world; sudden emergencies are no longer my habit. I crawl along. The white gaze, the only valid one, is already dissecting me. I am fixed. Once their microtomes are sharpened, the Whites objectively cut sections of my reality. I have been betrayed. I sense, I see in this white gaze that it's the arrival not of a new man, but of a new type of man, a new species. A Negro, in fact! (p. 95) 
With their thought processes and reality shaped by this White gaze, some Black individuals may become so transfixed by it that they develop, what Du Bois (1903/2018) presented in The Souls of Black Folk, a “double consciousness." This is described as an internal struggle between one's Black identity and the internalized oppressor's diminished projection of them.

\section{Rationale}

Two reasons inspired my decision to apply critical race theory as the theoretical framework for this research. Firstly, CRT provides a perspective that will allow me to identify and analyze some of the ways in which race and other social identities shape the experiences of Black 2SLGBTQ Caribbean-Canadian artists. Likewise, this may enable me to recognize how different social identities intersect with each other. This intersectional lens may allow me to identify important details and interpretations of the data collected.

Secondly, this theoretical framework coincides well with the nature of my research, as I will be examining the use of creative expression among a racialized community. As mentioned previously, CRT is known for its encouragement in using creativity as a means of disseminating the experiences and knowledge of oppressed people. Therefore, the aim of this research is, in part, to participate in the practice of centering and honouring the voices and knowledge of Black 2SLGBTQ Caribbean-Canadians.

This research utilizes critical race theory to examine the use of creative expression among Black 2SLGBTQ Caribbean-Canadian artists. CRT not only aligns with the focus of this research, but it may also provide me with an intersectional lens to identify important details and interpretations as I analyze the collected data. 


\section{CHAPTER 4. METHODOLOGY}

\section{Introduction}

This research utilized a multi-textual analysis research methodology and applied qualitative content analysis as a method to examine the data collected. Discussed in this chapter is my rationale for applying this approach and some of the limitations to its use. I will also outline the process of data collection and analysis.

\section{Research Questions}

Based on the theoretical framework discussed in Chapter Three, the focus of this research is on exploring the following two questions: 1) How do Black 2SLGBTQ Caribbean-Canadian artists use creative expression to navigate their gender and sexual identity within the context of culture and community? and 2) In what ways do their art practice resist/theorize/respond to heterosexism and/or anti-Black racism?

\section{Methodology}

As an extension of textual analysis, multi-textual analysis is a data-gathering process used to investigate how members of various cultures and subcultures engage with texts to express how they make sense of who they are and how they fit into the larger social context in which they live (McKee, 2011). Researchers using multi-textual analysis methodology are not limited to one singular form of text. Therefore, the data collected may include a variety of textual data, including drawings, interview transcripts, photographs, films, etc. (Julien, 2012; McKee, 2011). The term "text" refers to literature, films, photographs, narratives, television programmes, magazines, speeches, clothing, and so forth (Bouma, Ling \& Wilkinson, 2016; Julien, 2012; McKee, 2011). This approach is often applied by researchers in fields such as cultural studies, media studies, sociology, and philosophy (McKee, 2011). 
My rationale for selecting this methodology is twofold. Firstly, applying a multi-textual analysis approach allowed me to locate a variety of secondary data that were relevant to my research. This expanded my options to a wide range of artists and art practices. Because of my research questions and the theoretical framework applied in this study, this methodology offered me the opportunity to not be limited to one category of text to examine. This also considers the possibility that certain texts may be restrictive in ways that others are not, as certain ideas or topics may be expressed or engaged with differently, depending on the category of text.

Secondly, this methodology aligns with the theoretical framework on which this research is based. As mentioned in Chapter Three, one of the main features of CRT is the use of counterstorytelling (Delgado \& Stefancic, 2017; Ladson-Billings, 2000). Counter-storytelling is a political tool used to disrupt and resist oppressive dominant narratives (Delgado \& Stefancic, 2017; Ladson-Billings, 2000; McKenzie-Mohr \& Lafrance, 2017). This coincides with the aim of this research, which is to uncover the counter-stories expressed in the texts.

\section{Limitations}

It is important to note that there are some limitations to using a multi-textual analysis approach in this research. Firstly, there is a potential for some important details to be overlooked, which may result in my interpretation of the text differing from that of its creator (Atkinson, 2012; McKee, 2011). However, the position of this research is not to assume that there is one accurate interpretation of the collected data. Rather, it is to identify what interpretations are most likely in a given socio-cultural context, which aligns with one of the core features of multitextual analysis (McKee, 2011).

Secondly, there is also potential for my analysis of the data to be influenced by my connection to the topic (Atkinson, 2012). Alternative interpretations may consequently be 
overlooked. As mentioned previously, the position of this research is not to identify one true interpretation of each text. By engaging in critical self-reflexivity throughout this research process, I may be able to identify when my analysis is influenced by my connection to the topic and allow alternative meanings and interpretations to surface.

\section{Data Collection}

This research relied on two secondary data sources. The first textual data analyzed is the photography project titled Out of Many, One People by photographer Brianna Roye. This project is publicly available on Roye's website and is described as an ongoing series that captures 2SLGBTQ+ people who are of Caribbean descent. According to the "about" section of Roye's website, Roye is described as a Jamaican-Canadian photographer from Toronto, Canada who identifies as a queer androgynous woman. My initial review of her repertoire revealed that she is actively involved in Toronto's Black 2SLGBTQ community and is connected to other Black artists of various art practices. Roye's participation in the arts, as well as the nature of her photography series, coincides with the aim of this research study, making her an ideal candidate.

Also analyzed in this research is a 2015 video recording of an interview with CaribbeanCanadian artist Michèle Pearson Clarke titled Parade of Champions: Artist Talk. This interview is available publicly on Clarke's website. It features a discussion on Clarke's experience of creating her video installation Parade of Champions, which "explores the grief experiences of three black queer people, following the deaths of their mothers" (Clarke, n.d.). Other topics discussed in the interview include race, anti-Black racism, queerness, immigration, and intersectionality. As stated on her website, Clarke is described as a Trinidadian-born artist who works in film, photography, video, and installation. Similar to Roye, my review of Clarke’s 
collection of work revealed that she is active in Canada's art scene and has been featured in a number of interviews and art exhibits.

\section{Data Analysis}

The collected data was analyzed using qualitative content analysis. The primary objective of qualitative content analysis is to uncover any underlying meanings within a text by focusing on capturing definitions, meanings, processes, and types (Altheide \& Schneider, 2017; Atkinson, 2017; Bouma, Ling \& Wilkinson, 2016). As an analytic method, qualitative content analysis is described as the intellectual process of grouping textual data into similar conceptual categories to identify consistent patterns and relationships between variables and themes (Julien, 2012). By applying this approach, I recognize that the text examined is open to subjective interpretation and may have multiple meanings (Julien, 2012).

The data analysis phase began with a review of the content of the selected texts. My focus during this step was to develop categories by identifying and documenting significant components within the texts (Atkinson, 2012). Categories were refined in the proceeding steps. The next step entailed an individualized examination of each text to develop a more thorough analysis and to uncover any underlying meanings (Atkinson, 2012). Patterns between the selected texts were then examined. I discuss in the following chapter, the underlying meanings of the texts based on my research question and the theoretical framework applied. 


\section{CHAPTER 5. FINDINGS AND ANALYSIS}

This chapter discusses the key themes that emerged from my analysis of Brianna Roye's Out of Many, One People photography series and Michèle Pearson Clarke's Parade of Champions: Artist Talk interview. As noted in Chapter Four, I utilized a multi-textual analysis research methodology in this study and examined the collected data using qualitative content analysis. Three key themes were identified in my analysis: (1) creative expression used to engage with the individual-community-society interplay; (2) creative expression used to normalize Black 2SLGBTQ Caribbean-Canadian identity; and (3) creative expression used to disseminate knowledge.

\section{Individual-Community-Society Interplay}

One of the key themes to emerge from my analysis concerned the use of creative expression to engage with the individual-community-society interplay. This is evident in the artists' integration of aspects of their own social identities into their art practice. Brianna Roye's photography project, for instance, is described as an ongoing series that is centered around “capturing LGBTQ2S+ people who are of Caribbean descent" (Roye, n.d.). Strong parallels exist between the description of this project and the social identities with which Roye identifies, as noted in the "about" section of her website: "Brianna Roye is a Jamaican-Canadian photographer from Toronto, Ontario, who identifies as a queer androgynous woman” (Roye, n.d.).

Similarly, Michèle Pearson Clarke indicates in the following excerpt from her interview that her work is informed by her Black and queer identities:

In the development of the work [Parade of Champions], you have to present to classmates and stuff, and a couple of times I had to face that question, like, "If it's about grief, why does it have to be Black and queer?" That's just something that 
you have to deal with and you have to explain to people: "Well, I'm Black and queer. That's why it's Black and queer." (Clarke, 2015)

By including aspects of their own multiple and intersecting social identities, the artists' connection to the individuals presented in their work is made evident. This enhances their work, adding a layer of intimacy, vulnerability, and authenticity.

Roye and Clarke further activate the individual-community interaction to explore and discover insight into experiences common to those who share similar identities. For Clarke, this interaction influenced her own experience with grief following the death of her mother, aiding her in her healing journey:

This is an autobiographical project without me being in it. I have been completely confounded by my own experience of grief and part of my motivation of making this work was I was trying to understand my own grief by talking to people who share my subjectivity in the world....I wanted to do something that would bring grief from the private into the public. (Clarke, 2015)

Moreover, Roye and Clarke expand the individual-community interaction by exploring the broader social context of heterosexism, immigration, anti-Black racism and the African diaspora. Consider Roye's use of images and symbols to express 2SLGBTQ pride, strength, and freedom in the following photograph:

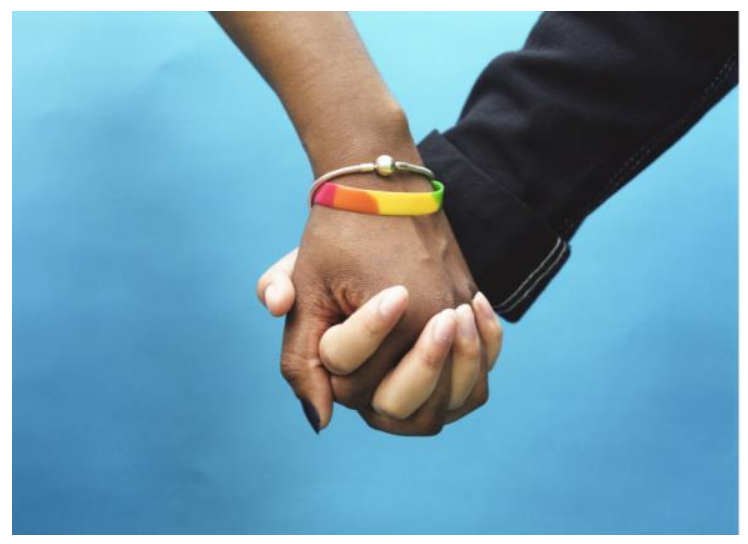

Figure 1: Out of Many, One People Two People Holding Hands (Roye, n.d.). 
In this photograph, Roye engages with the themes of 2SLGBTQ pride, strength, and freedom by depicting two people holding hands—one wearing a Pride bracelet—in front of a blue background that is reminiscent of a clear, expansive sky. Similar messages were identified in Figure 2:

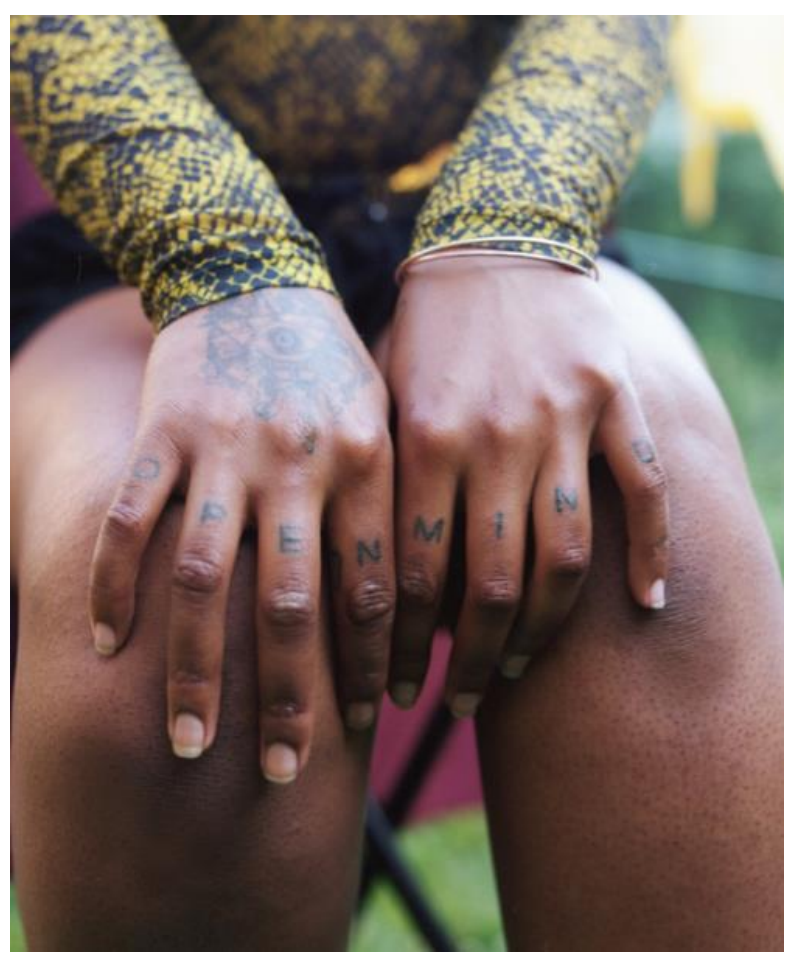

Figure 2: Out of Many, One People 'Open Mind' Tattoo (Roye, n.d.).

The main focal point of the above photograph is the tattoo displayed on the subject's fingers that reads "open mind." A subtle, yet deliberate, response to heterosexist ideologies is expressed through this image, revealing one of the underlying premises of Roye's project. Considering the nature of this project, one can conclude that Roye's inclusion of this image not only centers the Black 2SLGBTQ Caribbean experience, but it is also an act of resistance to heterosexism. 
The subject of immigration was also identified in Roye's project. This was depicted in the photograph of Jamaican-Canadian DJ Blackcat, a prominent figure in Toronto's 2SLGBTQ Caribbean-Canadian community (see Figure 3).

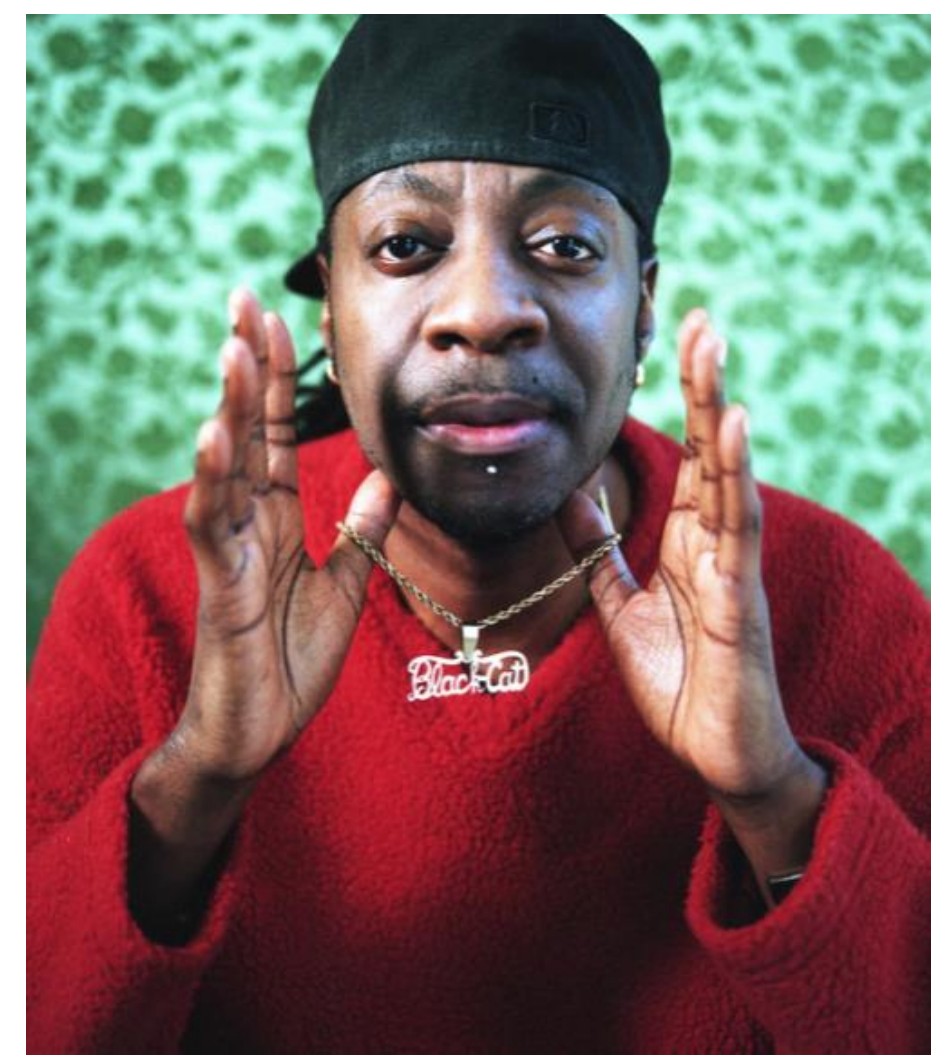

Figure 3: Out of Many, One People DJ Blackcat (Roye, n.d.).

Her inclusion of such an active and well-known member of the community is perhaps a nod to the ways in which Black 2SLGBTQ Caribbean-Canadian people have cultivated communities outside of their countries of origin, creating for themselves spaces where their voices, experiences, and identities are validated and celebrated.

The augmenting or diminishing of gender/sexual identities in relation to immigration was also highlighted by Clarke. In the following excerpt, she discusses how the universal experience of grief is further complicated for Black 2SLGBTQ-identified persons in this regard: 
Well, it's the diaspora. My mom immigrated here, so she was here with me. Whereas for my participants, there was all distance. So, everybody came to Toronto from somewhere else, and their mothers died not here. So, it was a phone call, it was travel, it was that negotiation of going back to a place and then having to navigate and negotiate the intersection of your Blackness and queerness because when you go back to where you came from, you're going back to the Blackness; and most of us, you can't leave the queerness behind, right? So, negotiating that in a time of grief, in a stressful time, what choices do you make around who's coming, who's not coming? "How out am I? Oh, I wanted to do this at the funeral but I can't." So, all of those things become compounded complexities...of the grief. (Clarke, 2015)

Expanding further, she places grief within the larger context of the African diaspora: In terms of Blackness, I think particularly for me - and for all of my subjects as well - the grief of the diaspora...is something that... a lot of us are born into. So, in my family, I was born into a family where my parents lived away from their parents, and their parents lived away from their parents; and that sense of displacement, that sense of movement that goes right back to that ancestral memory of being on that ship. So, that motion, that displacement, that loss is something that I think is present just in the state of being Black in the world. And I think we can all relate to the grieving of the...continued violence that we all have to bear witness to. (Clarke, 2015)

Identified in these two excerpts is a rather noteworthy submission: the universal experience of grief in response to loss is particularly complicated for some Black 2SLGBTQ persons, as it is compounded with heterosexism, anti-Black racism, and the historical and ongoing implications of these oppressive systems. Moreover, both Clarke and Roye utilize their art practices to engage in counter-storytelling, an important feature of critical race theory. Using creative expression as a form of resistance, these artists produce counter-stories that challenge and disrupt oppressive systems and narratives. It is 
through such innovative strategies of resistance that Black people have collectively overcome slavery and continue to fight to eradicate anti-Black racism and all forms of oppression.

Additionally, as Clarke exemplifies in the following excerpt, engaging with the individual-community-society interplay through creative expression may facilitate personal healing:

[The Parade of Champions installation] is an autobiographical piece without me being in it. So, so much of what my participants said I would say. So, that was tremendously healing and validating. And having a conversation with three people about their moms was just nice....It's just nice to talk to people about their moms who they're missing. (Clarke, 2015)

Clarke's art practice provides for her an opportunity to grapple with several complex issues that extend across multiple levels (i.e., individual, community, society). For her, using creative expression to engage with the individual-community-society interplay is a practice of self-care, one that promotes healing and enhances her understanding of difficult circumstances. This point is further demonstrated in the following excerpt from her interview:

Making the work is self-care in a lot of ways....The whole process of constructing the visual representation and stripping it away, and thinking really about how do we take care of this person and show this person and present this person was...very interesting....I think as artists, you share. Like, when you share this stuff and the conversations people have with you and their own reactions and their own responses, that's self-care, right? (Clarke, 2015)

\section{Normalizing Black 2SLGBTQ Caribbean Identity}

The second key theme to emerge involves the use of creative expression to normalize Black 2SLGBTQ Caribbean identity. This was evident in the ways Roye and 
Clarke presented the relationship that Black 2SLGBTQ Caribbean people have to universal experiences (e.g., grief) or expressions that signify love, safety, joy, confidence and so forth. There are many ways that Roye illustrates this in her project, including in the following photograph that depicts two individuals sitting in a home, joined in an embrace with their eyes closed:

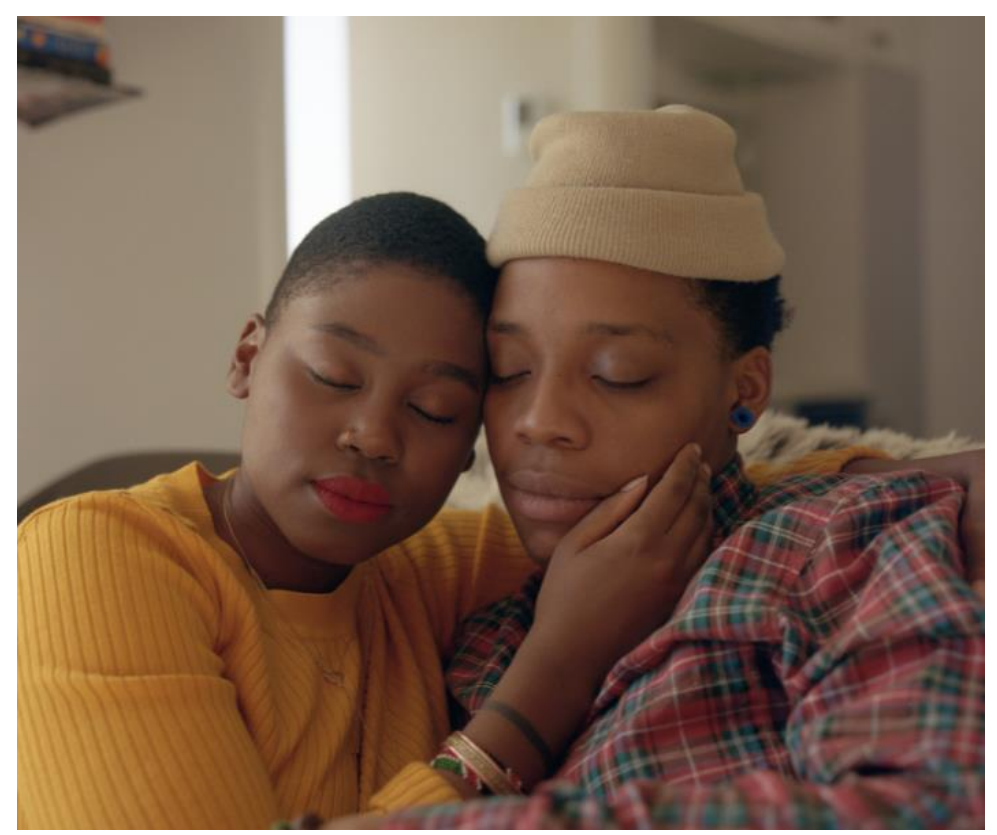

Figure 4: Out of Many, One People Two People Embracing (Roye, n.d.).

And again in the following photograph of two individuals sitting in bed reclined against each other, eyes closed: 


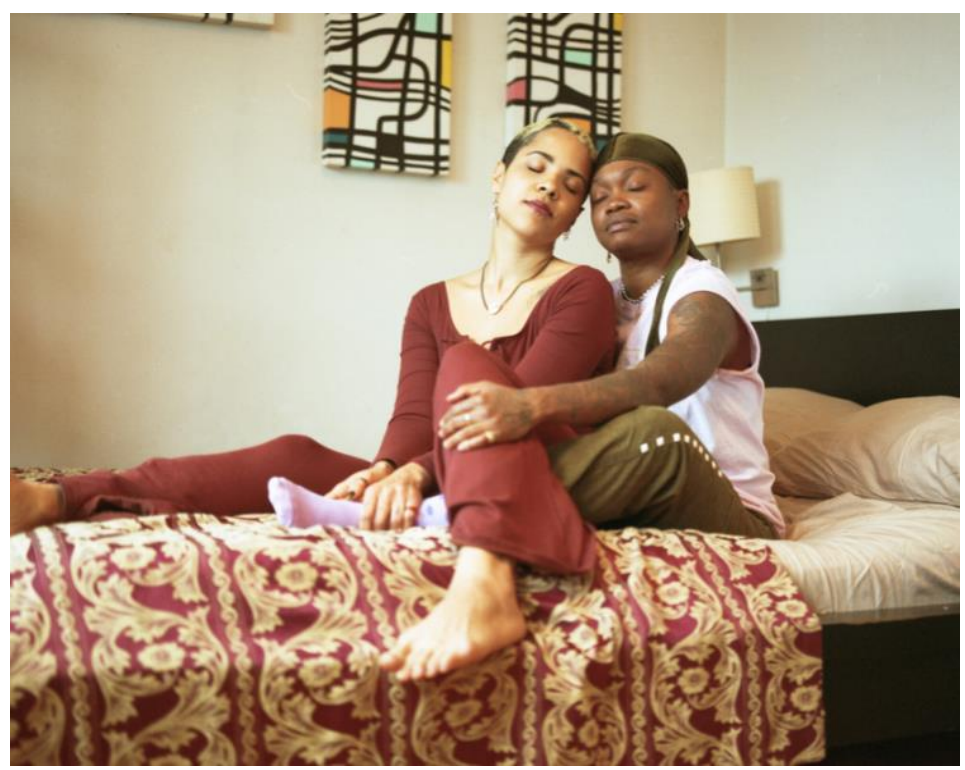

Figure 5: Out of Many, One People Two People Embracing in Bed (Roye, n.d.).

Roye continues in the same vein in the below photograph of two people in a public setting riding piggyback in a fashion that expresses playfulness, intimacy, and warmth:

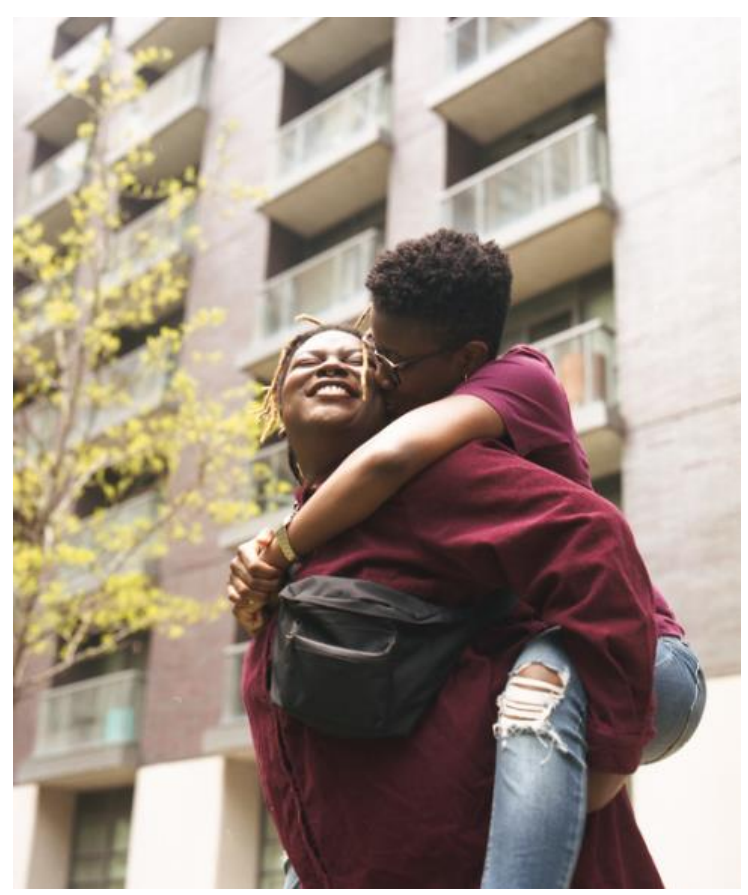

Figure 6: Out of Many, One People Two People Riding Piggyback (Roye, n.d.).

Roye's use of expressions (i.e., closed eyes, closeness, touch), as well as settings (i.e., home, bedroom, public space), appear to be a deliberate effort to demystify Black 
2SLGBTQ Caribbean identity and partnership. The settings and expressions used in these photographs evoke a sense of safety, peace, comfort, intimacy, playfulness, belonging, love, and freedom. By capturing her subjects in this manner, Roye prompts the viewer to consider the ways they identify with the moments and experiences depicted in the photographs. This disrupts the sense of otherness and detachment and invites viewers to notice their connection with the individuals presented.

Additionally, both Clarke and Roye appear to be intentional about representing their subjects in a manner that honours their resilience and dignity. This is exhibited in the following photograph from Roye's project of an individual standing bare-chested holding a rose:

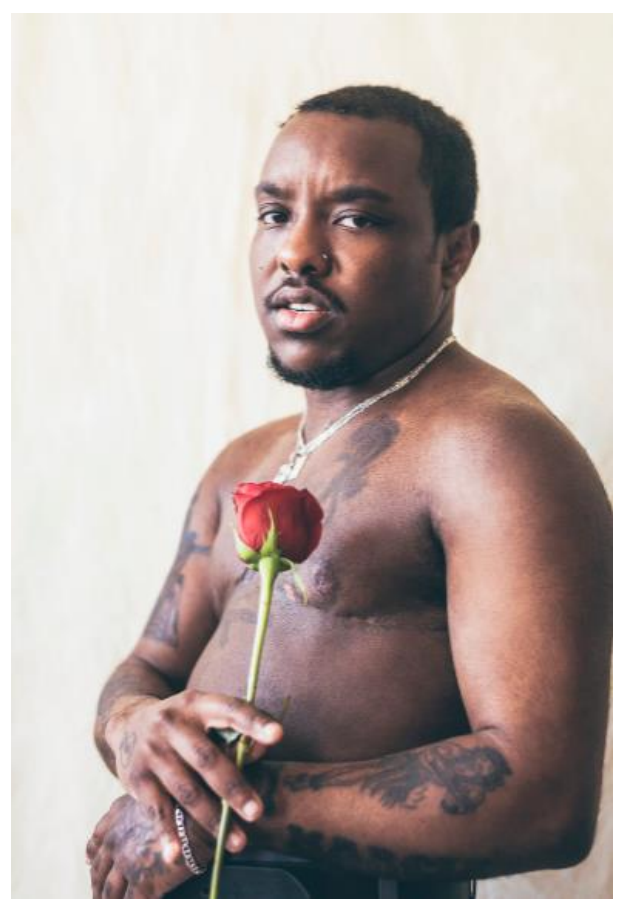

Figure 7: Out of Many, One People Marcus (Roye, n.d.).

A number of symbols are used in the above photograph to express tenderness, poise, love, vulnerability, and strength. For example, the subject stands bare-chested with a relaxed gaze, holding a single rose. Here, both the individual and the rose are exposed 
(i.e., the isolated rose; the individual uncovered). This evokes a sense of oneness between subject and object. In presenting this utter bareness and vulnerability, Roye simultaneously compels the viewer to also witness the individual's dignity and strength.

This approach to normalizing Black 2SLGBTQ Caribbean-Canadian identity places emphasis on intentional representation. The artist inserts thoughtfulness, intention, and awareness into how her subjects are presented and the underlying purpose of the presentation. This was also identified in my analysis of Clarke's interview, particularly in the following excerpt:

With this work, I was very aware of the spectacle of Black pain that is common in visual representations; and this work is about Black pain, I'm not shying away from that. And I was very mindful of how I was going to represent Blackness in this work and I wanted to create something that was full of grace. I wanted to create something that was poetic. I wanted to create something that would allow Black bodies to be viewed in a gentle, still way, as opposed to...representations of Black queerness...as victims of homophobia, as victims of violence, as victims of family rejection....I wanted to do something that was different. (Clarke, 2015) Roye and Clarke's effort to normalize Black 2SLGBTQ Caribbean identities through their art practices is simultaneously a response to anti-Black racism and other systems of oppression that are connected to it. Colonialism and White supremacy, specifically, are challenged as oppressive systems that perpetuate the exploitation and domination of Black people. These systems are further disrupted by Roye and Clarke's centering of Black 2SLGTBQ Caribbean identities, thus rejecting dominant narratives that position White male heterosexual patriarchy as the norm.

\section{Disseminate Knowledge}


The final theme identified in my analysis involves the use of creative expression to disseminate knowledge regarding the experiences of Black 2SLGBTQ CaribbeanCanadian people. Centering their knowledge, bringing it out from the peripheries, not only affirms and validates their experiences and identities, but it also asserts their sense of belonging. An example of this was identified in the title of Roye's photography project: "Out of Many, One People." This title is borrowed from the national motto of Jamaica. It is common knowledge that this motto refers to the diverse cultural and racial identities of the island's population. Roye's use of "Out of Many, One People" as the title of her project can be interpreted as a reclamation of space for 2SLGBTQ people within Caribbean identity. In other words, this project is an expression of resistance to systemic and cultural erasure of 2SLGBTQ Caribbean identities and experiences. Roye's declaration of 2SLGBTQ Caribbean inclusion and belonging is further illustrated through her use of objects associated with Caribbean cultural identity. Consider the following photograph: 


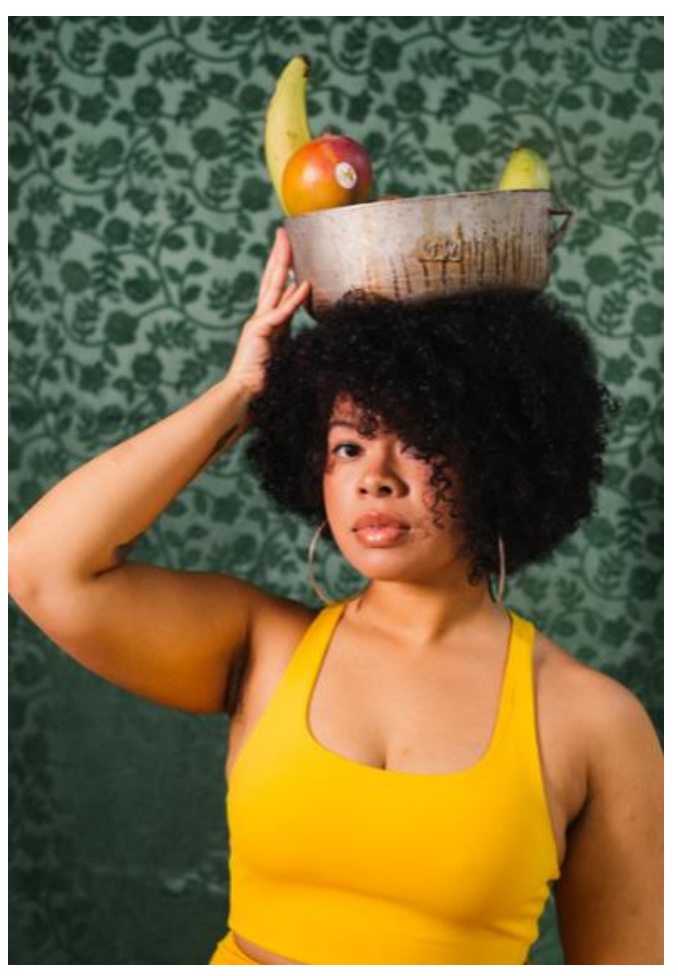

Figure 8: Out of Many, One People Person Carrying a Dutch Pot (Roye, n.d.).

In the above image, Roye incorporates symbols often associated with Caribbean cultural identity, including a Dutch pot, a mango, and plantains. In addition, the subject's pose is akin to scenes common to Caribbean food markets, namely the familiar imagery of Caribbean women carrying baskets of produce on their heads.

Likewise, Roye employs colours in her work to further illustrate this statement of belonging and 2SLGBTQ inclusion (see Figure 9). 


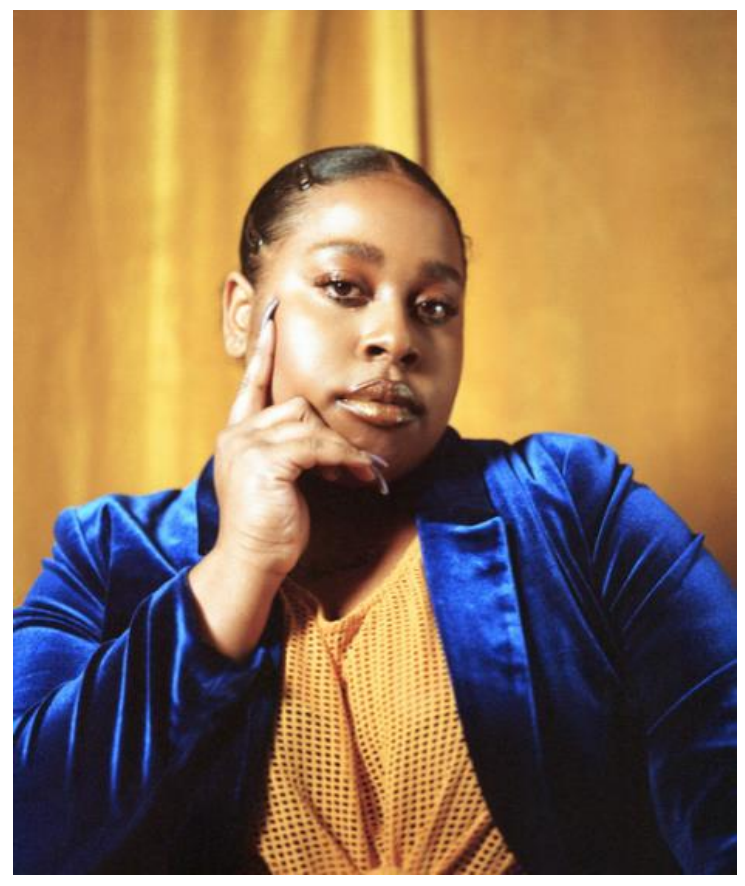

Figure 9: Out of Many, One People Person Dressed in Blue and Gold (Roye, n.d.).

Figure 9 depicts a person with long, darkly painted nails, dressed in a royal blue blazer and a gold-coloured top underneath. These colours, and the layering of the subject's outfit, are reminiscent of the flag of Barbados. Again, Roye merges subject and object; and in doing so, a subtle yet powerful message is conveyed: 2SLGBTQ identity does not exist separate from Caribbean culture. In other words, 2SLGBTQ Caribbean people belong. Their identities are valid and cannot be erased.

Using their art practices, Roye and Clarke bring to the fore the realities and knowledge unique to members of this population. They utilize creative expression to share nuanced perspectives that may run counter to dominant narratives. For example, on the topic of familial acceptance of Black 2SLGBTQ Caribbean-Canadian persons, Clarke stated:

One of the realizations that I came to was my mother loved me unconditionally in my Blackness, in my queerness....In working with my participants, I guess I assumed that they had the same relationship....But all of my participants actually, 
I would say, were kind of on a spectrum around how their mothers felt about their queerness. But what was universal was that deep sense of unconditional love, that deep sense of acceptance of who you were, even if they didn't quite understand it. (Clarke, 2015)

Here, Clarke activates the individual-community-society interaction to bring forward the knowledge of those whose experience with familial acceptance may be deemed an exception to the norm. Expanding further on the topic, Clarke stated:

I think another piece for me is there's a dominant...cultural narrative that Black people are more homophobic than everybody else. And I feel like it's damaging to Black people — and White people — because...if a Black family believes that myth then they kind of get taught that they only have one option. And Black queer people may choose to not give their families a chance to know them because that is such a powerful myth. And not to minimize the very real pain and rejection that many Black queer people have to face, but so many of us are loved by our families and grief is the price you pay for love. So, this piece is a testimony to that familial love, to that familial acceptance, and sort of a push back against that idea that there's only one family story for Black queer people. (Clarke, 2015)

The counter-narrative presented here aims to interrupt the notion that Black families of 2SLGBTQ persons are more homophobic than their non-Black counterparts. Using her art practice, Clarke interrupts this dominant narrative, presenting a counter-narrative that demonstrates that Black families of 2SLGBTQ individuals are neither innately homophobic nor restricted to one family story. While it remains true, as Clarke stated, that some Black 2SLGBTQ individuals do experience familial rejection, the exclusion of this alternative story may contribute to the reproduction of the dominant narrative and its damaging impact. In this regard, creative expression is used to center this alternative story and make examples of it more accessible to the public. 
Additionally, Clarke utilizes creative expression to share knowledge on the ways that familial acceptance can contribute greatly to fostering a sense of empowerment and safety among Black 2SLGBTQ Caribbean-Canadian individuals. As she explains in the following excerpt, her sense of empowerment can be attributed to the support and acceptance she received from her mother:

...I have lots of privileges that buffer what is happening to me and, in a lot of ways, my mom herself is such a buffer even though she's not here....Because I grew up with a woman who was full of grace....I have that as a developmental...well to draw on. (Clarke, 2015)

Expanding on this topic, she uses her art practice to offer insight into the particular type of grief that some Black 2SLGBTQ individuals may experience in response to the loss of a loved one:

...[E]ven just as a buffer for my daily experiences of sexism or racism or homophobia, [my mother's] love was like this buffer, you know? I have never known fear and anxiety the way I know it now. It's really shifted my relationship to risk.... I feel more vulnerable just in general without her. And I think all of my participants are speaking to that type of loss, that type of absence, that void.

(Clarke, 2015)

Highlighted here is the complex nature of this particular form of grief experienced by some Black 2SLGBTQ individuals. It is a form of grief that is compounded with the loss of an important source of safety and acceptance. Using her art practice to once again engage with the individual-community interaction, Clarke offers valuable knowledge that may contribute to efforts by social workers to better meet the needs of members of this particular community.

In the following chapter, I present the implications of this research for social work practice and offer suggestions for future research on this topic. 


\section{CHAPTER 6. IMPLICATIONS}

This section discusses the significance of this research, in addition to its limitations. The significance of this research is twofold: (1) it affirms the importance of applying a critical race theory (CRT) framework to social work practice; and (2) it allows social work practitioners to consider practices that facilitate greater inclusion and support for Black 2SLGBTQ communities and individuals.

\section{CRT in Social Work Practice}

Firstly, this research affirms the importance of applying a CRT framework to social work practice. This framework embraces social justice initiatives and places primacy on centering the knowledge systems and experiences of those oppressed by race, class, gender, and sexual identity (Bell, 1995; Ladson-Billings, 2000). This aligns with core social work principles and values, particularly to promote social justice and advocate for social change (Ontario College of Social Workers and Social Service Workers, 2018). CRT complements and enriches social workers' existing strengths by providing a framework for identifying and addressing racism and other intersecting systems of oppression that permeate social institutions, structures, and policies (Kolivoski, Weaver \& Constance-Huggins, 2014). By offering insight into the use of creative expression as a form of resistance to oppression, this research may contribute to ongoing discussions and efforts to eradicate anti-Black racism and heterosexism.

Social workers informed by a CRT framework may consider, for instance, the connection between creative expression and social activism. This connection was well demonstrated by the artists in this research in that they utilized their art practices to resist and respond to heterosexism and anti-Black racism. One can interpret this to be a form of activism. As Baines (2011) described in Bridging the Practice-Activism Divide in Mainstream Social Work: Advocacy, 
Social Organizing, and Social Movements, activism may entail organizing, educating, and mobilizing people in pursuit of social justice; and while it involves certain skills and knowledge, it can be practiced by anyone.

Further examples of Black 2SLGBTQ artists who actively engage in social justice activism through their art practice include Ravyn Wngz and Syrus Marcus Ware. In Black Arts and the Movement: A Conversation, Wngz and Ware (2020) describe the importance of integrating social activism into their art practices as artists and members of Black Lives MatterToronto. For Ware, inspiration comes, in part, from other social justice movements, namely the Black Panther Party:

...I had the chance to meet Emory Douglas, and he was the revolutionary artist for the Black Panther Party. And that was his official title. He recreated this work, used the art, his art, so intentionally in that movement, to engage communities, particularly poor and working-class communities, to get involved in the fight and to get involved in organizing and to get involved in supporting things in their community. Then he used his art practice to promote the programming of the Panthers: the free clinics, the breakfast programs, the free food programs. By using art and design, he created a branding and an identity for the Panthers that was hard to ignore, right? And I think we're seeing that a lot with the Black Lives Matter movement as well, where there's these movement colours of black and gold and there's just a particular aesthetic, a certain kind of Black activist aesthetic right now. (Wngz \& Ware, 2020, p. 139-140)

This suggests that the convergence of social activism and creative expression has the potential to advance social justice initiatives, in addition to influencing future social justice movements. 
Likewise, Wngz utilizes dance and movement to navigate the emotional impact of protesting and care for members of the community. Reflecting on using creative expression during Black Lives Matter-Toronto's 2016 protest outside Toronto Police Headquarters in response to anti-Black racism and police brutality, Wngz stated:

It was so intensely traumatic and violent in so very many ways I felt like I had to go in that space and dance and create a space for people to stretch and for people to move and for people to move the violence out of their bodies and out of their personal space....And so now, when we march down the street, we dance and we chant. We create rhythms that allow us to keep moving and keep excitement and keep people engaged in a way that makes them feel powerful. When you're marching down the street with those, you feel powerful....It's scary. But it's also exciting because you're part of something so much larger than yourself while utilizing something that is your art practice. I think it's one of those really powerful gifts, where you understand why you have the gifts you have. (Wngz \& Ware, 2020, p. 140-141)

Wngz's reflection exemplifies the "individual-community-society interplay" discussed in Chapter Five, in addition to demonstrating that utilizing creative expression to resist and respond to systemic oppression has the potential to inspire and unite members of marginalized communities. This is consistent with existing literature suggesting that engaging in creative art practices and artistic communities can significantly assist Black and 2SLGBTQ people of colour in constructing their social identities within cis-heteronormative and anti-2SLGBTQ cultures (Aiyer, 2020; Wilson 2007). Additionally, members of these communities may also gain a sense 
of validity, liberation and hope, as engaging in their art practices offers them a platform on which to express their intersecting identities (Aiyer, 2020; Diverlus et al, 2020; Levitt et al., 2018).

\section{Black 2SLGBTQ Inclusion and Support}

Secondly, this research may also allow social work practitioners to consider practices that facilitate greater inclusion and support for Black 2SLGBTQ communities and individuals. As presented in Chapter Five, creative engagement can be a means of centering the experiences and knowledge of marginalized communities. The knowledge produced through these creative processes can be used to inform the development of services, resources and support to address heterosexism and anti-Black racism. Consider, for example, the integration of talk therapy and the creative arts in micro-level social work practice. As other studies have shown, this approach may produce a significant reduction of symptoms of depression, anxiety, and PTSD, in addition to promoting overall mental health and wellness (Akthar \& Lovell, 2018; Dieterich-Hartwell \& Koch, 2017; Tyrer \& Fazel, 2014). This was identified in Chapter Five wherein Michèle Pearson Clarke stated in her interview that engaging in her art practice facilitated insight and healing, allowing her to process the death of her mother. Wngz also highlighted this connection between creative expression and healing at a community level:

I'm excited about the healing. I don't know if people think about us that way, but I guess that's what it is. If I was to create more art that was specifically dealing with the BLM movement, I want to show more of the healing aspect of what we do: the communities that we've brought together to fight this massive beast of institutional everything, the healing spaces, friendship. (Wngz \& Ware, 2020, p. 142) 


\section{Limitations}

There are some limitations to this research that are important to note. Firstly, this study may be limited by the small number of secondary data sources examined. Consequently, a narrow perspective on the topic examined may have been presented. Future research should consider interviewing a greater number of individuals to capture a broader range of varying perspectives.

Secondly, due to the use of a multi-textual analysis methodology in this study, there is a potential for misinterpretations of the collected data, in addition to particular insight being excluded or overlooked. While the position of this research is not to assume that there is one accurate interpretation of the data collected (a position that aligns with one of the core features of multi-textual analysis [McKee, 2011]), it is important to note that some interpretations of the text may differ from that of the artists. Future research should consider using primary data collection methodologies. For example, an openended interview approach with participants discussing their knowledge and reflections on their experiences as Black 2SLGBTQ Caribbean-Canadian artists may produce more indepth information on the topic. 


\section{CHAPTER 7. CONCLUSION}

Current literature that examines the experiences of Black 2SLGBTQ communities in Canada reveals that some members are vulnerable to unique forms of oppression due to their intersecting identities. Members of this population are exposed to anti-Black racism and cisheterosexism, and are also underrepresented both within the larger 2SLGBTQ community and Caribbean community in Canada (Abreu, 2016; DeGagné, 2018; Toth, 2011; Wahab \& Plaza, 2009; Ware, 2017). This research applied a CRT theoretical framework to explore the following two questions: 1) How do Black 2SLGBTQ Caribbean-Canadian artists use creative expression to navigate their gender and sexual identity within the context of culture and community? and 2) In what ways do their art practice resist/theorize/respond to heterosexism and/or anti-Black racism?

Two secondary data sources were analyzed in this research using a multi-textual analysis research methodology and qualitative content analysis. The first textual data examined was the photography project Out of Many, One People by Jamaican-Canadian photographer Brianna Roye. Also examined was an interview with Trinidadian-Canadian artist Michèle Pearson Clarke wherein she discussed her experience of creating her video installation Parade of Champions, in addition to topics such as anti-Black racism, queerness, and immigration.

Three key themes were identified in my analysis. The first key theme identified was the use of creative expression to engage with the individual-community-society interplay. These artists use their art practices to explore and discover insight into experiences common to those who share similar identities. They also use their art practice to grapple with several complex issues that extend across multiple levels (i.e., individual, community, society). Secondly, these artists use creative expression to normalize Black 2SLBGTQ Caribbean identity. Both artists, 
with a focus on representing their subjects in a manner that honours their resilience and dignity, utilized their art practices to prompt viewers to consider the ways they identify with the moments and experiences presented. Finally, my analysis revealed that these artists use creative expression to disseminate knowledge regarding the experiences of Black 2SLGBTQ Caribbean-Canadian people, which not only affirms and validates their identities, but it also asserts their sense of belonging.

This research supports the importance of applying a CRT framework to social work practice. Social workers informed by this framework may consider the connection between creative expression and social activism, which was well demonstrated by the artists in this research who utilized their art practices to resist and respond to heterosexism and anti-Black racism. Moreover, this research may also allow social work practitioners to consider practices that facilitate greater inclusion and support for Black 2SLGBTQ communities and individuals. As discussed in Chapter Five, creative engagement can be a means of centering the experiences and knowledge of marginalized communities. The knowledge produced through these creative processes can be used to inform the development of services, support, and resources to address heterosexism, anti-Black racism, and other forms of systemic oppression.

Engaging in this research has not only expanded my understanding of the use of creative expression as a means of resisting and responding to systemic oppression, but it has also been affirming in several ways. This research afforded me the privilege of being exposed to creative projects by artists whose intersecting identities resemble my own. As a Black queer CaribbeanCanadian, it has been a powerful experience witnessing others in their process of claiming space and showcasing dignified representations of Black 2SLGBTQ Caribbean identities. As such, I 
have been inspired both as a musician and a social worker. I am motivated to continue exploring and participating in the use of art and creative expression to elicit social change.

This study may be limited by the use of a multi-textual analysis methodology and by the small sample size analyzed. Future research should consider using a larger sample to capture a broader range of varying perspectives, in addition to using primary data collection methodologies. An open-ended interview approach with participants discussing their knowledge and reflections on their experiences as Black 2SLGBTQ Caribbean-Canadian artists may generate more in-depth information on the topic. Nonetheless, by offering insight into the use of art and creative expression as a form of resistance to oppression, this research may contribute to ongoing discussions and efforts to promote Black 2SLGBTQ equity and inclusion. 


\section{References}

Abreu, D. (2016, May 21). Dancehall's proliferation of homophobia: Sizzla, and much of dancehall culture, incites grotesque homophobic violence. Medium.

https://medium.com/writings-on-whatever-i-wanted/dancehalls-proliferation-ofhomophobia-a4c4f88d2f2f

Aiyer, P. (2020). Queering poetics: The impact of poetry on LGBT+ identity in Singaporean adolescents. Journal of Homosexuality, 67(2), 206-222.

https://doi.org/10.1080/00918369.2018.1536415

Akthar, Z. \& Lovell, A. (2018). Art therapy with refugee children: A qualitative study explored through the lens of the art therapists and their experiences. International Journal of Art Therapy, 24(3), 139-148. https://doi.org/10.1080/17454832.2018.1533571

Alessi, E. J., Khan, S. \& R. Van Der Horn. (2017). A qualitative exploration of the premigration victimization experiences of sexual and gender minority refugees and asylum seekers in the United States and Canada. The Journal of Sex Research, 54(7), 936-948. https://doi.org/10.1080/00224499.2016.1229738

Altheide, D. L. \& Schneider, C. J. (2017). Qualitative media analysis. 55 City Road, London: SAGE Publications.

Atkinson, J. D. (2012). Journey into social activism: Qualitative approaches. Fordham University Press.

Baines, D. (2011). An overview of anti-oppressive social work practice: Neoliberalism, inequality, and change. In D. Bains (Ed.), Doing anti-oppressive practice: Social justice social work (2nd ed., pp. 25-47). Fenwood Publishing. 
Baines, D. (2011). Bridging the practice-activism divide in mainstream social work: Advocacy, organizing, and social movements. In D. Baines (Ed.), Doing anti-oppressive practice: Social justice social work (2nd ed., pp. 79-94). Halifax, N.S.: Fernwood Publishing.

Bell, D. (1995). Who's afraid of critical race theory. University of Illinois Law Review, 1995(4), 893-910.

Benjamin, A. L. (2003). The black/Jamaican criminal: The making of ideology. [Unpublished doctoral dissertation]. University of Toronto.

Benn, A. (2017). The black queer youth initiative: Challenging racism, stigma \& exclusion. In A. Abramovich \& J. Shelton (Eds.), Where am I going to go? Intersectional approaches to ending LGBTQ2S youth homelessness in Canada \& the U.S. (pp. 217-228). Canadian Observatory on Homelessness.

Bouma, G. D., Ling, R., \& Wilkinson, L. (2016). The research process (3rd ed.). Oxford University Press.

Cader, F. \& Amofah, B. A. (2016, November 28). Why do discussions about carding ignore the experiences of women and trans people? Now. https://nowtoronto.com/news/cardingracial-profiling-women-trans-people/

Charles, C. A. D. (2011). Representations of homosexuality in Jamaica. Social and Economic Studies, 60(1), 3-29.

Chen, J. M. (2017). The contentious field of Whiteness studies. Journal for Social Thought, 2(1), $15-27$.

Clarke, M. P. (n.d.). Video installation: Parade of championships. Michèle Pearson Clarke. https://www.michelepearsonclarke.com/parade-of-champions/ 
Clarke, M. P. (2015, June 12). Parade of champions: Artist talk [Video]. Vimeo. https://vimeo.com/130579024

Cooper, A. (2006). The Hanging of Angelique. Toronto, ON: HarperCollins.

Crenshaw, K. (2018). Demarginalizing the intersection of race and sex: A Black feminist critique of antidiscrimination doctrine, feminist theory, and antiracist politics [1989]. In Feminist legal theory (pp. 57-80). Routledge.

Davis, A. J. (Ed.). (2017). Policing the black man. New York, NY: Pantheon Books.

DeGagné, A. (2018). On anger and its uses for activism. Contemporary Inequalities and Social Justice in Canada, 142-163.

Delgado, R. \& Stefancic, J. (2017). Critical race theory: An introduction (3rd ed.). New York University Press.

Deliovsky, K. \& Kitossa, T. (2013). Beyond black and white: When going beyond may take us out of bounds. Journal of Black Studies, 44(2), 158-181. https://doi.org/10.1177/0021934712471533

d'Entremont, P. E. (Director). (2012). Last Chance. [Film]. National Film Board of Canada.

Dieterich-Hartwell, R. \& Koch, S. (2017). Creative art therapies as temporary home for refugees: Insights from literature and practice. Behavioral Science, 7(4). https://doi.org/10.3390/bs7040069

Du Bois, W. E. B. (2018).The Souls of Black Folk. New York, NY: Penguin Books. (Original work published 1903)

Fanon F. (1952). Black skin white mask. Grove Press. 
Ghabrial, M. (2014). "Trying to figure out where we belong": Narratives of racialized sexual minorities on community, identity, discrimination, and health. (Publication No. 10185633) [Master's thesis, University of Toronto]. ProQuest Dissertation.

Gillborn, D., \& Ladson-Billings, G. (2019). Critical Race Theory. In P. Atkinson, S. Delamont, A. Cernat, J.W. Sakshaug, \& R.A. Williams (Eds.), Research Methods Foundations. SAGE Publications. http://dx.doi.org/10.4135/9781526421036764633

Giwa, S. \& Greensmith. (2012). Race relations and racism in the LGBTQ community of Toronto: Perceptions of gay and queer social service providers of color. Journal of Homosexuality, 59, 149-185.

Gollom, M. (2016, July 5). Black Lives Matter got attention, but did its Pride tactics hurt or help its cause? CBC News. https://www.cbc.ca/news/canada/toronto/black-lives-mattertoronto-pride-parade-1.3663659

Hill, M. (2013). Is the Black community more homophobic?: reflections on the intersectionality of race, class, gender, culture and religiosity of the perception of homophobia in the Black community. Journal of Gay \& Lesbian Mental Health, 17, 208-214. Taylor \& Francis Group. https://doi.org/10.1080/19359705.2013.768089

Hopkinson, R. A., Keatley, E., Glaeser, E., Erickson-Schroth, L., Fattal, O., \& Sullivan, M. N. (2017). Persecution experiences and mental health of LGBT asylum seekers. Journal of Homosexuality, 64(12), 1650-1666. http://dx.doi.org/10.1080/00918369.2016.1253392

Hunter, M. (2002). Rethinking epistemology, methodology, and racism: Or, is White sociology really dead?. Race \& Society, 5(2), 119-138. https://doi.org/10.1016/j.racsoc.2004.01.002 
Hunter, M. A. (2010). All the gays are white and all the blacks are straight: Black gay men, identity, and community. Sexual Research and Social Policy, 7, 81-92. Springer. https://doi.org/10.1007/s13178-010-0011-4

Human Rights Watch. (2004). Hated to death: Homophobia, violence and Jamaica's HIV/AIDS epidemic. https://www.hrw.org/report/2004/11/15/hated-death/homophobia-violence-andjamaicas-hiv/aids-epidemic

Human Rights Watch. (2014, October 21). Jamaica: Unchecked homophobic violence. https://www.hrw.org/news/2014/10/21/jamaica-unchecked-homophobic-violence

Humphrey, C. (2007). Insider-outsider: Activating the hyphen. Action Research, 5(2) 11-26. https://doi.org/10.1177\%2F1476750307072873

Jackman, M. (2016). They called it the 'abominable crime': An analysis of heterosexual support for anti-gay laws in Barbados, Guyana and Trinidad and Tobago. Sexuality Research and Social Policy, 13, 130-141. Springer. DOI 10.1007/s13178-015-0209-6

Janssen, D.J. \& Scheepers, P. (2019). How religiosity shapes rejection of homosexuality across the globe. Journal of Homosexuality, 66(14), 1974-2001. https://doi.org/10.1080/00918369.2018.1522809

Julien, H. (2012). Content analysis. In L. M. Given (Ed.), The SAGE encyclopedia of qualitative research methods (pp. 121-122). SAGE Publications.

Julien, I. (Director). (1996). The Darker Side Of Black [Film]. Filmakers Library.

Keleta-Mae, N. (2020). Black Lives Matter: Toronto sit-in at Pride. In R. Diverlus, S. Hudson, \& S. M. Ware, S. M. (Eds.), Until we are free: Reflections on Black Lives Matter in Canada (pp. 263-275). University of Regina. 
Kolivoski, K. M., Weaver, A. \& Constance-Huggins, M. (2014). Critical race theory: Opportunities for application in social work practice and policy. Families in Society: The Journal of Contemporary Social Services, 95(4), 269-276. https://doi.org/10.1606/10443894.2014.95.36

Ladson-Billings, G. (2000). Racialized discourses and ethnic epistemologies. In N. Denzin \& Y. Lincoln (Eds.), Handbook of qualitative research (2nd ed., pp. 257-277). SAGE Publications.

Lawrence, B. \& Dua, E. (2005). Decolonizing antiracism. Social Justice, 32(4), 120-143.

Lavers, M. (2019, August 8). Lawsuits in four Caribbean countries challenge colonial-era sodomy laws. Washington Blade. https://www.washingtonblade.com/2019/08/08/lawsuits-in-four-caribbean-countrieschallenge-colonial-era-sodomy-laws/

LaViolette, N. (2009). Independent human rights documentation and sexual minorities: An ongoing challenge for the Canadian refugee determination process. The International Journal of Human Rights, 13(2-3), 437-476. https://doi.org/10.1080/13642980902758234

Levitt, H. M., Surace, F. I., Wheeler, E. E., Maki, E., Alcántara, D., Cadet, M., Cullipher, S., Desai, S., Sada, G. G., Hite, J., Kosterina, E., Krill, S., Lui, C., Manove, E., Martin, R. J. \& Ngai, C. (2018). Drag gender: Experiences of gender for gay and queer men who perform drag. Sex Roles, 78, 367-384. https://doi.org/10.1007/s11199-017-0802-7.

Majied, K. F. (2015). Racism and homophobia in Cuba: A historical and contemporary overview. Journal of Human Behaviour in the Social Environment, 25, 26-34. Taylor \& Francis Group. https://doi.org/10.1080/10911359.2014.953428 
Maynard, R. (2017). Policing Black lives: State violence in Canada from slavery to the present. Halifax, NS: Fernwood Publishing.

McKee, A. (2011). Textual analysis: A beginner's guide. SAGE Publications.

McKenzie-Mohr, S. \& Lafrance, M. (2017). Narrative resistance in social work research and practice: Counter-story in the pursuit of social justice. Qualitative Social Work, 16(2), 189-205. https://doi.org/10.1177\%2F1473325016657866

Miller, K. (2017). YMCA Sprott house: Creating a better space for LGBTQ2S youth in Toronto. In A. Abramovich \& J. Shelton (Eds.), Where am I going to go? Intersectional approaches to ending LGBTQ2S youth homelessness in Canada \& the U.S. (pp. 169181). Canadian Observatory on Homelessness Press.

Mulé, N. \& Gates-Gasse, E. (2012). Envisioning LGBT refugee rights in Canada: Exploring asylum issues. Envisioning Global LGBT Human Rights. https://ocasi.org/downloads/Envisioning_Exploring_Asylum_Issues.pdf

Mullings, D. V., Morgan, A., \& Quelleng, H. K. (2016). Canada the great white north where anti-Black racism thrives: Kicking down the doors and exposing the realities. Phylon, 53(1), 20-41.

Murray, D. A. B. (2014). The challenge of home for sexual orientation and gendered identity refugees in Toronto. Journal of Canadian Studies/Revue d'études canadiennes, 48(1), 132-152. University of Toronto Press. https://doi.org/10.3138/jcs.48.1.132

Neilhart, M. (1998). Creativity, the arts, and madness. Roeper Review, 21(1), 47-50. Taylor \& Francis Group.

O’Neill, B. J., Swan, T. A. \& Mulé, N. J. (Eds.). (2015). LBGTQ people and social work. Toronto: Canadian Scholars' Press. 
Ontario College of Social Workers and Social Service Workers. (2018). Code of ethics and standards of practice. https://www.ocswssw.org/professional-practice/code-of-ethics/

Ontario Human Rights Commission. (2018). A collective impact: Interim report on the inquiry into racial profiling and racial discrimination of Black persons by the Toronto Police Service. http://www.ohrc.on.ca/en/public-interest-inquiry-racial-profiling-anddiscrimination-toronto-police-service/collective-impact-interim-report-inquiry-racialprofiling-and-racial-discrimination-black\#Endnotes

Pon, G. (2009). Cultural competency as new racism: An ontology of forgetting. Journal of Progressive Human Services, 20(1), 59-71. http://dx.doi.org/10.1080/10428230902871173

Pyne, J. (2015). Transfeminist theory and action: Transwomen and the contested terrain of women's services. In B. J. O’Neill, T. A. Swan, \& N. J. Mule, (Eds.). (2015). LBGTQ people and social work (pp. 129-150).Toronto: Canadian Scholars' Press.

Quinn, K. \& Dickson-Gomez, J. (2015). Homonegativity, religiosity, and the intersecting identities of young Black men who have sex with men. AIDS \& Behaviour, 20, 51-64. Springer. https://doi.org/10.1007/s10461-015-1200-1

Ray, V. E., Randolph, A., Underhill, M., \& Luke, D. (2017). Critical race theory, Afropessimism, and racial progress narratives. Sociology of Race and Ethnicity, 3(2), 147158. SAGE Publications. https://doi.org/10.1177/2332649217692557

Roye, B. (n.d.) Out of many, one people [Photography series]. http://www.briannaroye.com/outof-many-one-people 
Shum, D. (2016, September 20). Pride Toronto ‘regrets’ Black Lives Matter Toronto parade protest flip-flop. Global News. https://globalnews.ca/news/2951045/pride-torontoregrets-black-lives-matter-toronto-parade-protest-flip-flop/

Smith, A. (2006). Heteropatriarchy and the three pillars of White supremacy: Rethinking women of color organizing. In A. Smith, B. E. Richie \& J. Sudbury (Eds.), Color of violence: The Incite! anthology (1st ed., pp. 66-73). South End Press.

Steinmetz, K. (2015, August 17). Why transgender people are being murdered at a historic rate. Time. https://time.com/3999348/transgender-murders-2015/

Stuckey, H. L. \& Nobel, J. (2010). The connection between art, healing and public health: A review of current literature. American Journal of Public Health, 100(2) 254-263. https://doi.org/10.2105/AJPH.2008.156497

Toth, K. (2011, July 28). DJ Blackcat wants to queer Caribana: Scotiabank Caribbean carnival still struggles with homophobia. Xtra. https://www.dailyxtra.com/dj-blackcat-wants-toqueer-caribana-24690

Truth and Reconciliation Commission of Canada. (2015). Honouring the truth, reconciling for the future: Summary of the final report of the Truth and Reconciliation Commission of Canada. http://www.trc.ca/assets/pdf/Honouring_the_Truth_Reconciling_for_the_Future_July_23 _2015.pdf

Tuck, E. \& Yang, K. W. (2012). Decolonizing is not a metaphor. Decolonization: Indigeneity, Education \& Society, 1(1), 1-40. 
Tyrer, R. \& Fazel, M. (2014). School and community-based interventions for refugee and asylum seeking children: A systematic review. PLoS ONE, 9(2). https://doi.org/10.1371/journal.pone.0089359

Wahab, A. \& Plaza, D. (2009). Queerness in the transnational Caribbean-Canadian diaspora. Caribbean Review of Gender Studies, 3, 1-34. The University of the West Indies.

Walcott, R. \& Abdillahi, D. (2019). BlackLife: Post-BLM and the struggle for freedom. Winnipeg: APR Books.

Ware, S. M. (2017). All power to all people? Black LGBTTI2QQ activism, remembrance, and archiving in Toronto. Transgender Studies Quarterly, 4(2), 170-180. Duke University Press. https://doi.org/10.1215/23289252-3814961

Wilson, D. M. (2007). Post-pomo hip-hop homos: Hip-hop, art gay rappers, and social change. Social Justice, 34(1), 117-140.

Wngz, R \& Ware, S. M. (2020). Black arts and the movement: A conversation. In R. Diverlus, S. Hudson, \& S. M. Ware, S. M. (Eds.), Until we are free: Reflections on Black Lives Matter in Canada (pp. 133-150). University of Regina.

Wortley, S., \& Owusu-Bempah, A. (2011). "The usual suspects": Police stop and search practices in Canada. 21:4 Policing \& Society, 21(4), 395.

Xtra Magazine. (2020, February 11). Canadian rapper Sydania on finding self-acceptance | Inspired |Xtra. [Video]. Youtube. https://www.youtube.com/watch?v=-RKN7JwDwtc Yee, J. Y. (2005). Critical anti-racism praxis: the concept of whiteness implicated. In S. Hick, J. Fook \& R. Pozzuto (Eds.), Social work: A critical turn (pp. 87-104). Thompson Educational Publishing. 